\title{
Genetic and epigenetic control of gene expression by
}

\section{CRISPR-Cas systems [version 1; peer review: 3 approved]}

\author{
Albert Lo1, Lei Qi (iD)-3 \\ ${ }^{1}$ Department of Bioengineering, Stanford University, Stanford, CA 94305, USA \\ 2Department of Chemical and Systems Biology, Stanford University, Stanford, CA 94305, USA \\ ${ }^{3} \mathrm{ChEM}-\mathrm{H}$, Stanford University, Stanford, CA 94305, USA
}

V1 First published: 25 May 2017, 6(F1000 Faculty Rev):747

https://doi.org/10.12688/f1000research.11113.1

Latest published: 25 May 2017, 6(F1000 Faculty Rev):747

https://doi.org/10.12688/f1000research.11113.1

\section{Abstract}

The discovery and adaption of bacterial clustered regularly interspaced short palindromic repeats (CRISPR)-CRISPR-associated (Cas) systems has revolutionized the way researchers edit genomes. Engineering of catalytically inactivated Cas variants (nuclease-deficient or nuclease-deactivated [dCas]) combined with transcriptional repressors, activators, or epigenetic modifiers enable sequencespecific regulation of gene expression and chromatin state. These CRISPR-Cas-based technologies have contributed to the rapid development of disease models and functional genomics screening approaches, which can facilitate genetic target identification and drug discovery. In this short review, we will cover recent advances of CRISPR-dCas9 systems and their use for transcriptional repression and activation, epigenome editing, and engineered synthetic circuits for complex control of the mammalian genome.

Keywords

CRISPR, Cas, dcas

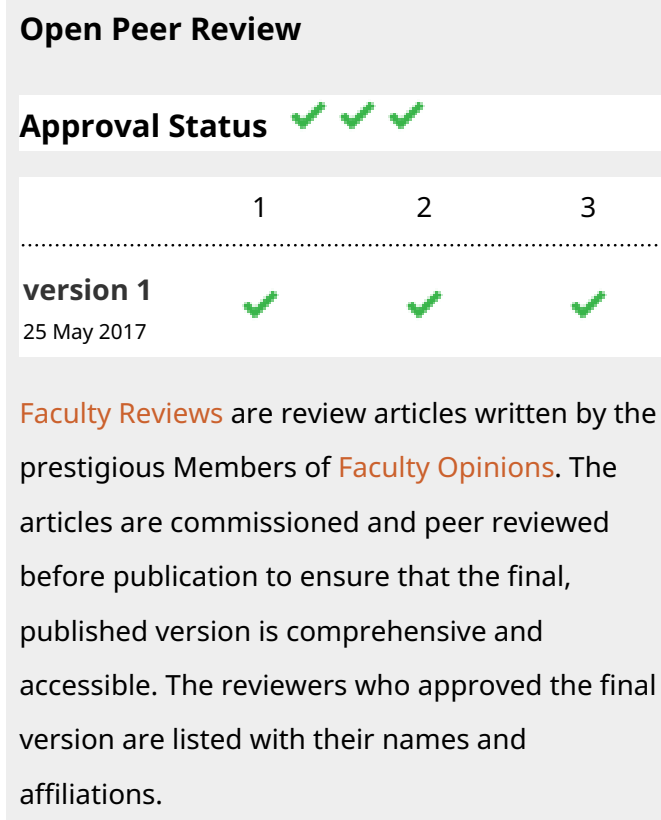

Faculty Reviews are review articles written by the prestigious Members of Faculty Opinions. The articles are commissioned and peer reviewed before publication to ensure that the final, published version is comprehensive and accessible. The reviewers who approved the final version are listed with their names and affiliations.

1. Luciano Marraffini, Rockefeller University, New York, USA

2. Charles Gersbach, Duke University, Durham, USA

3. Rodolphe Barrangou, North Carolina State University, Raleigh, NC, USA

Any comments on the article can be found at the end of the article. 
Corresponding author: Lei Qi (slqi@stanford.edu)

Competing interests: The authors declare that they have no competing interests.

Grant information: This work was supported by DP5 OD017887, Pew Scholar Fellowship, and Sloan Research Fellowship (L.S.Q).

The funders had no role in study design, data collection and analysis, decision to publish, or preparation of the manuscript.

Copyright: $\odot 2017$ Lo A and Qi L. This is an open access article distributed under the terms of the Creative Commons Attribution License, which permits unrestricted use, distribution, and reproduction in any medium, provided the original work is properly cited.

How to cite this article: Lo A and Qi L. Genetic and epigenetic control of gene expression by CRISPR-Cas systems [version 1; peer review: 3 approved] F1000Research 2017, 6(F1000 Faculty Rev):747 https://doi.org/10.12688/f1000research.11113.1

First published: 25 May 2017, 6(F1000 Faculty Rev):747 https://doi.org/10.12688/f1000research.11113.1 


\section{Introduction}

Many pathological conditions such as metabolic disorders, cardiovascular diseases, cancer, or other common diseases are often attributed to dysregulated gene expression ${ }^{1-3}$. The development of methods that can accurately control gene expression contributes to our understanding of cellular physiology, which is essential for both basic biological research and the advancement of medicine. Gene expression is a multistep process that involves coordinated control of transcription, translation, and turnover of messenger RNAs (mRNA) and proteins ${ }^{4}$. Precise regulation of the process by which DNA becomes RNA on the transcriptional or epigenetic level is the first step to fully control this sophisticated process.

In the past few years, RNA-guided sequence-specific genome editing and regulation technologies have been developed based on the discovery of the clustered regularly interspaced short palindromic repeats (CRISPR)-CRISPR-associated (Cas) systems. The rapid development of these tools has come after years of research on CRISPR biology, which reveals that bacteria and archaea use CRISPR-associated, RNA-guided DNA endonucleases to defend themselves from invading foreign genetic elements ${ }^{5-17}$. According to their protein sequence homology and CRISPR repeat identity, the CRISPR-Cas systems discovered so far have been categorized into two major classes and six types using bioinformatics methods ${ }^{18-20}$. The class 1 CRISPR system, which requires a large complex of several effector proteins, is divided into types I, III, and IV. In contrast, in the class 2 CRISPR system, which is divided into types II, V, and VI, only one RNA-guided endonuclease is required to mediate the cleavage of invading genetic elements $^{13,18,21}$. Due to their simplicity, the class 2 CRISPR-Cas systems have been mostly employed for genome-engineering applications. In particular, the type II CRISPR-Cas9 systems have been used in a variety of organisms including microbes ${ }^{22-25}$, fungi ${ }^{26-29}$, plants $^{30-40}$, and animals $\mathrm{s}^{41-46}$.

In the type II CRISPR-Cas systems, a Cas9 endonuclease and a guide RNA, which consists of a DNA-targeting CRISPR-associated RNA (crRNA) and the trans-activating crRNA (tracrRNA), establish a functional guide RNA-Cas9 complex $^{10}$. The CRISPR-Cas9 complex is recruited to the target DNA site by its guide RNA, which has a 20 nucleotide sequence complementary to its target. The DNA target must be adjacent to a short stretch of DNA sequence termed protospacer-adjacent motif (PAM) ${ }^{47}$, which is compatible with the type of Cas9 being employed. The endonuclease activity of Cas9 thus causes a double strand break (DSB) at the target site $^{8}$. To simplify the use of the CRISPR-Cas9 systems for genome-engineering applications, a seminal study demonstrated that crRNA and tracrRNA could be engineered into a chimeric single guide RNA (sgRNA), which is easily programmable and portable (Figure 1A) ${ }^{6}$. Adaptation of CRISPR-Cas9 systems from prokaryotes has spurred the development of genome-editing tools in eukaryotes ${ }^{41,42,48-51}$. Through the generation of a sequencespecific DSB by Cas9 in the host, the error-prone DNA repair pathway (non-homologous end joining) will be triggered, which often results in insertion/deletion (indel) mutations at the site of editing. Alternatively, by providing a separate DNA template containing sequences homologous to the regions flanking the
DSB, Cas9 can facilitate targeted incorporation of the repair template into the genomic DNA by homology-directed repair (HDR). A summary of CRISPR-Cas9-based genome-engineering applications is provided in Figure 1C. Detailed reviews on CRISPR-Cas systems for gene editing can be found in 52-54.

Beyond gene editing, CRISPR-Cas9 has been repurposed as a genome-docking platform that allows for a broad range of genome-

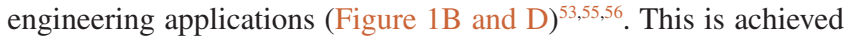
by ablating the nuclease activity of Cas 9 by creating mutations in the RuvC and $\mathrm{HNH}$ nuclease domains, which are conserved among Cas9s from various bacterial species. The resulting nuclease-deactivated Cas9 (dCas9) is a generic RNA-guided DNA-binding molecule which cannot cleave DNA but still retains its ability to bind to specific DNA sequences ${ }^{57}$. dCas 9 can be further engineered into programmable artificial transcription factors in eukaryotic cells to modulate gene expression when coupled with transcriptional repressors or activators, as illustrated below. The structural information about the CRISPR-Cas system has guided, and will continue to guide, the engineering efforts for applications ${ }^{53,58}$.

\section{CRISPR-dCas9 for transcriptional repression: CRISPR interference}

The first demonstration of dCas9-based repression was in bacteria, where it was shown that dCas9 is able to abrogate the transcription of targeted genes either by disrupting transcription factor binding or by interfering with transcriptional elongation ${ }^{57,59-61}$ (Figure 2A, left). As bacterial cells lack the machinery for RNA interference, this technique allows for research into gene function that was not previously possible in microbes. As CRISPR-dCas9 interferes with the transcription of the targeted genes by sterically hindering the elongation of RNA polymerase (RNAP) or inhibiting the initial binding of RNAP to the promoter, this approach is termed CRISPR interference (CRISPRi). Studies also demonstrate that CRISPRi is highly specific with minimal off-target effects in bacterial cells and allows for tunable regulation of individual genes and multiplexable control of many genes using multiple $\operatorname{sgRNAs}{ }^{57,60}$. Exploring these unique features, CRISPRi has been applied to systematically interrogate the function of essential genes for their roles in growth, death, drug resistance, and morphology control ${ }^{62}$.

Although CRISPRi using only dCas9 and an sgRNA is highly efficient and can silence gene expression by up to $99.9 \%$ in prokaryotes $^{57}$, it achieves only modest repression (up to $60-80 \%$ ) of fluorescent reporter genes or tested endogenous genes in mammalian cells $s^{63,64}$. It is possible that the dCas9-sgRNA complex alone is not sufficient to fully block the action of the RNAP complex in eukaryotic cells. To improve the repression efficiency, dCas 9 has been fused with a number of repressive transcriptional or epigenetic effector domains, including the KRAB (Krüppelassociated box) domain of Kox1, the CS (chromoshadow) domain of HP1 $\alpha$, the WPRW domain of Hes1, or four concatenated copies of the mSin3 interaction domain (SID4X) ${ }^{63,65,66}$. Among these, KRAB-dCas9 fusion-mediated transcriptional repression is proven to be relatively robust, which can lead to downregulation of the endogenous gene in the range of 90 to $99 \%$ with a properly designed sgRNA ${ }^{63,66}$ (Figure 2A, right). 
A

CRISPR-Cas9 gene editing system

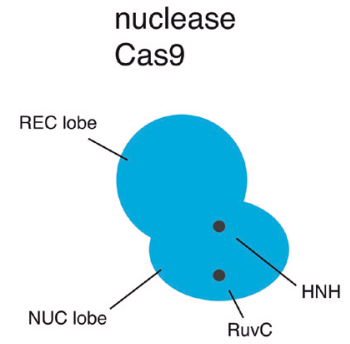

target-specific sgRNA

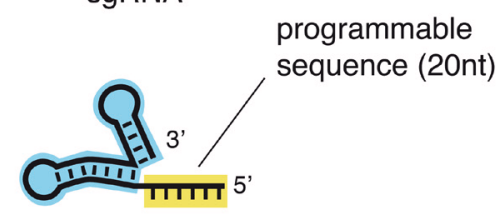

B

\section{CRISPR-dCas9 gene regulation system}

nuclease-deactivated dCas9

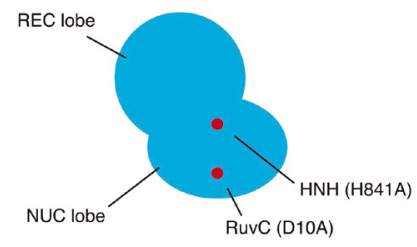

C

\section{CRISPR-Cas9-based applications}
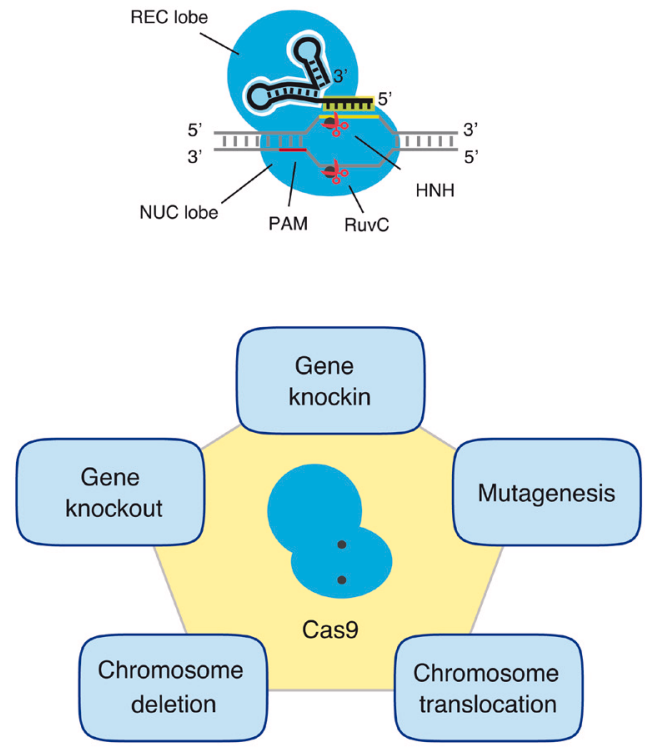

\section{target-specific} sgRNA

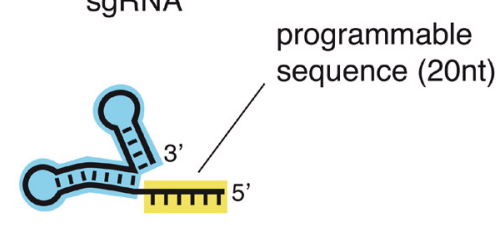

D

\section{CRISPR-dCas9-based applications}

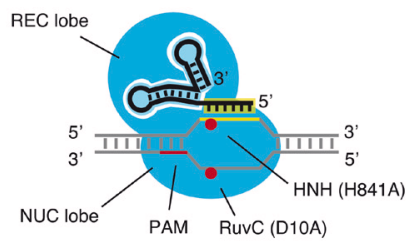

Figure 1. Clustered regularly interspaced short palindromic repeats (CRISPR)-CRISPR-associated 9 (Cas9) systems for genome editing and gene regulation. A. CRISPR-Cas9-mediated site-specific genome editing is accomplished by an RNA-guided DNA nuclease protein and a programmable single guide RNA (sgRNA). B. Nuclease-deficient Cas9 (dCas9) is engineered by introducing mutations (H841A and D10A) into catalytic residues of the $\mathrm{HNH}$ and RuvC nuclease domains. dCas9 therefore becomes a universal RNA-guided DNAbinding protein. C. Summary of CRISPR-Cas9-based genome engineering applications. D. Summary of CRISPR-dCas9-based genome engineering applications. PAM, protospacer-adjacent motif. 
A

Transcriptional repression (CRISPRi)

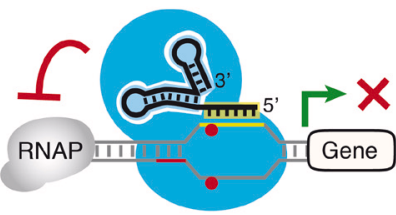

dCas9 only

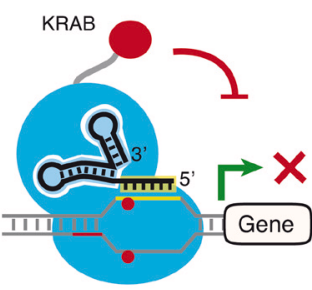

dCas9-KRAB
C
B

\section{Transcriptional activation (CRISPRa)}

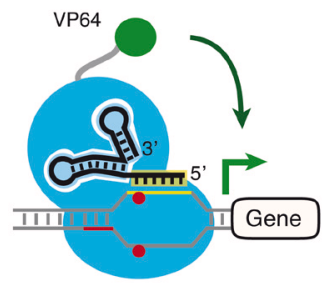

dCas9-VP64

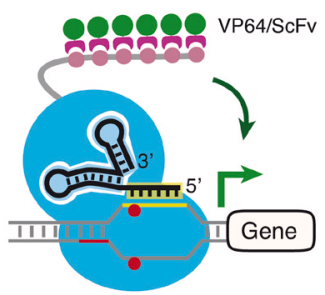

dCas9-Suntag

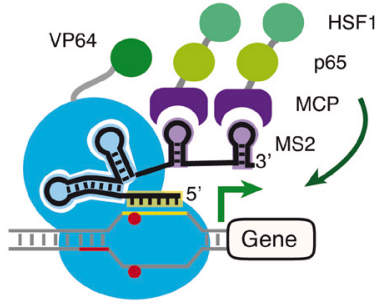

dCas9-SAM

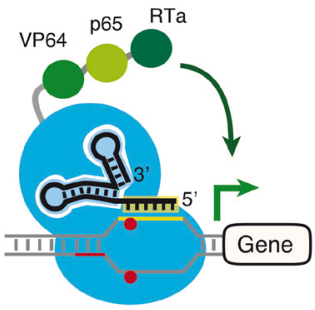

dCas9-VPR

\section{Epigenome engineering}

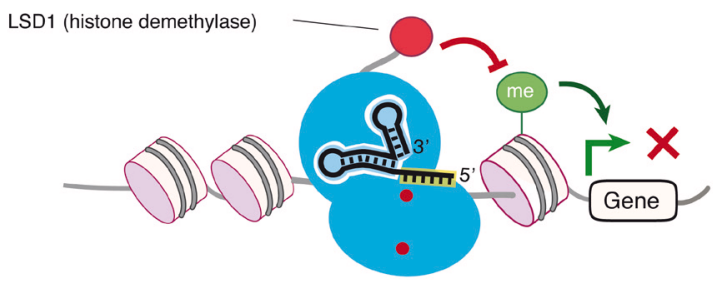

dCas9-LSD1

p300 (histone acetyltransferase)
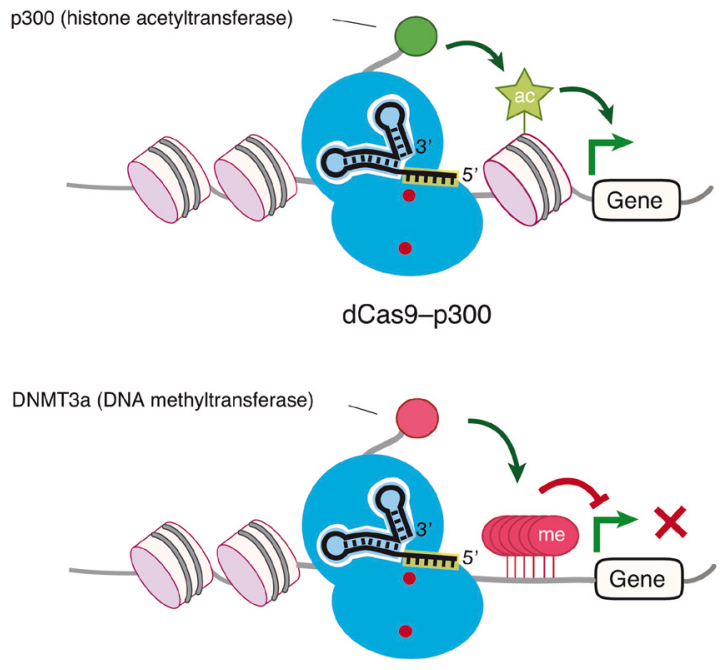

dCas9-DNMT3a

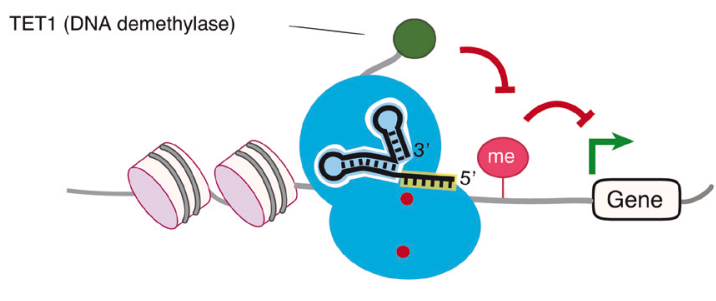

Figure 2. Control of gene expression by clustered regularly interspaced short palindromic repeats (CRISPR)-nuclease-deficient CRISPR-associated 9 (dCas9) systems. A. CRISPR interference (CRISPRi) for gene repression. The CRISPR-Cas9 complex can interfere with the assembly of RNA polymerases (RNAPs) at the transcriptional initiation step or disrupt the elongation of RNAPs to abrogate gene expression. In addition, a transcriptional repressor such as Krüppel-associated box (KRAB) can be coupled with dCas 9 to achieve gene repression. B. CRISPR activation (CRISPRa) for gene expression. dCas9 can be tethered with a transcriptional activator, for instance: 1) four copies of the herpes simplex viral protein 16 (VP16) activation domain (dCas9-VP64); 2) an aptamer-based recruitment system termed synergistic activation mediator (SAM), which uses combinatorial RNAs including single guide RNA (sgRNA) and MS2 RNA aptamers to recruit the MS2 bacteriophage coat protein (MCP) fused with p65 and heat shock factor 1 (HSF1); 3) a SunTag system that utilizes an array of small peptide epitopes to recruit multiple copies of single-chain variable fragment (scFv) fused with VP64; 4) a tandem fusion of three transcriptional activators including VP64, p65, and the Epstein-Barr virus R transactivator (RTa), or VPR, to augment gene expression. C. CRISPR-dCas9-based epigenome engineering. DNA and histone landmarks can be programmed in a designer manner by coupling dCas9 with specific epigenetic modifiers. For instance, fusing LSD1 demethylase with dCas9 can erase methylation of histone H3 lysine 4 (H3K4me2) near the enhancer region to abrogate gene expression, whereas the dCas9-p300 acetyltransferase chimeric protein increases acetylation of histone $\mathrm{H} 3$ lysine 27 (H3K27) at the enhancer and promoter to enhance gene expression. Alternatively, the DNA methylation status at the CpG-rich promoter can be modulated by a DNA methyltransferase (DNMT3a) or demethylase (TET1) to repress or augment gene expression, respectively. 
To understand the rules for designing sgRNAs for effective transcriptional repression, high-throughput screens using 54,810 sgRNAs tiled within a 10 kilobase window near the transcription start sites (TSS) of 49 genes have been performed in K562 myelogenous leukemia cells ${ }^{66}$. These experiments demonstrate that repression efficiency is strongly affected by the binding sites of the sgRNAs. In general, strong repression activity is observed by targeting the window of DNA from -50 to $+300 \mathrm{bp}$ relative to the TSS of a gene, with a maximum in the $\sim 50-100$ bp region just downstream of the TSS. Moreover, using sgRNAs with a statistical spacer length of 18-21 nucleotides achieves efficient repression, whereas the targeted DNA strand and guanine-cytosine (GC) content of sgRNA are not critical factors in successful CRISPRi implementation ${ }^{66}$.

\section{CRISPR-dCas9 for transcriptional activation: CRISPR activation}

In addition to coupling with transcriptional repressors, dCas9 can be fused with a transcriptional activator to drive target gene expression (Figure 2B). This CRISPR-dCas9-based gene activation is termed CRISPR activation (CRISPRa). In bacteria, fusion of the $\omega$ subunit of RNAP to the dCas9 can upregulate reporter gene expression up to 3-fold in Escherichia coli $^{59}$. Further tool development is needed for the practical implementation of CRISPRa in bacterial cells. For instance, characterization of additional transcriptional activators that function in bacterial cells is necessary for enhanced activation efficiency. Furthermore, testing how a given transcriptional activator functions in broad species of bacteria will be important to understand the true utility of the method in the kingdom of microbes.

In contrast to those in microbes, more CRISPRa tools have been developed for mammalian cells. dCas9 has been fused to various transcriptional activators, including the transactivation domain of NF- $\kappa \mathrm{B}$ p65 subunit (p65AD), the Herpes simplex viral protein 16 (VP16), or multiple tandem copies of VP16, such as VP64 (four copies, Figure 2B) or VP160 (10 copies) ${ }^{67,68}$. While these simple fusion proteins are able to activate the expression of reporters or endogenous genes, the potency of these constructs in transcriptional activation is quite modest, about 2-fold to 5-fold on average when using a single sgRNA ${ }^{63,67,69-71}$. The effectiveness of CRISPRa can be increased by using multiple sgRNAs tiled across the promoter of the target gene, which is tedious and sometimes challenging, as it requires co-delivery of many sgRNAs simultaneously ${ }^{67,70}$.

Several attempts have been made to improve the efficiency of CRISPRa. One approach is to amplify the activation signal from the transcriptional activator VP64 ${ }^{66,72}$. This is achieved by fusing a scaffold to dCas9 that is able to recruit many copies of VP64. This scaffold consists of a tandem array of antibody epitopes, named SunTag array, which can specifically interact and recruit multiples copies of a single-chain variable fragment ( $\mathrm{scFv}$ ) fused to VP64

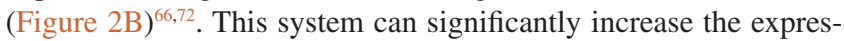
sion of endogenous genes, e.g. CXCR4, up to 50-fold in human erythroleukemia K562 cells with a single sgRNA as compared to a 2-fold increase observed with dCas9-VP64 fusion ${ }^{73}$. Using dCas9-SunTag, potent activation of CXCR4 is shown to promote cell migration ${ }^{72}$.

Another approach to augment transcriptional activation is by tethering multiple different activators to the dCas9. Researchers have fused dCas9 with a tripartite transactivator composed of VP64, p65AD, and Epstein-Barr virus $\mathrm{R}$ transactivator (Rta) (VPR) in tandem (Figure 2B) ${ }^{74}$. The dCas9-VPR system exhibits improved activation of endogenous coding and non-coding genes using multiple sgRNAs when compared with dCas9-VP64 fusion. This system is shown to direct the neuronal differentiation of induced pluripotent stem cells by using multiple sgRNAs against each target gene ${ }^{74}$.

A third approach is to use sgRNAs as scaffolds to recruit multiple transactivators that can function synergistically in enhancing the activation of endogenous genes. This method is referred to as the synergistic activation mediator (SAM) system (Figure 2B) ${ }^{75}$. This system is composed of a modified sgRNA containing two copies of an MS2 RNA hairpin (from the MS2 bacteriophage). Each MS2 hairpin recruits a pair of its cognate RNA-binding protein MS2 bacteriophage coat protein (MCP), which is fused with p65AD and heat shock factor 1 (HSF1). When combined with dCas9-VP64, the SAM system is shown to robustly activate endogenous coding and non-coding genes and has been employed for genome-wide screening for genes that confer resistance to a BRAF inhibitor ${ }^{75}$.

While these CRISPRa systems all exhibit significant enhancement in terms of target gene activation efficiency compared to dCas9-VP64 fusion, systemic comparisons reveal their ability to robustly activate gene expression in a range between 10-- and 1,000 -fold depending on the specific gene being perturbed ${ }^{76}$. Moreover, these systems function effectively in a variety of mammalian cell types, including human, mouse, and Drosophila. Attempts to further enhance efficiency by combining elements from VPR, SAM, and SunTag have been unsuccessful, suggesting that our understanding of the synthetic activation of endogenous genes in the genome is still limited ${ }^{76}$. Next-generation CRISPRa systems should incorporate novel activation domains, very likely by combining them with synergistic epigenetic modifiers to drive highly effective gene activation.

\section{CRISPR-dCas9 for epigenome editing}

Epigenetic modifications of the genome provide an important mechanism for heritable gene expression ${ }^{77-81}$. Modifications of the chromatin DNA or associated histones are correlated with distinct transcription states and disease phenotypes. For instance, promoters with silenced transcription exhibit distinct methylation or acetylation marks (e.g. histone H3 lysine 9 [H3K9] methylation, histone H3 lysine 27 [H3K27] methylation, and/or DNA methylation), while promoters with active transcription are associated 
with other unique patterns of modifications (e.g. histone acetylation or histone $\mathrm{H} 3$ lysine 4 [H3K4] methylation). Tools that allow us to precisely modify epigenetic marks at a given locus will be critical for understanding the basic and translational epigenetics. Since CRISPR-dCas9 allows for highly specific genomic targeting, its site-specific recruitment of chromatin-modifying epigenetic enzymes has been tested for sequence-specific epigenome editing (Figure 2C).

By coupling histone demethylase LSD1 with dCas9, this fusion protein is able to effectively repress pluripotency maintenance genes (e.g. Oct4 and Tbx3) by using sgRNAs to target the enhancer regions of these genes in mouse embryonic stem cells ${ }^{82}$. Decreased expression of target genes is correlated with reduced levels of $\mathrm{H} 3 \mathrm{~K} 4$ dimethylation (H3K4me2) and $\mathrm{H} 3 \mathrm{~K} 27$ acetylation (H3K27ac) near the enhancer regions. Loss of expression of these pluripotency maintenance genes eventually causes morphological changes in embryonic stem cells ${ }^{82}$. Interestingly, the dCas9-KRAB fusion protein can also induce the repressive trimethylation of $\mathrm{H} 3 \mathrm{~K} 9$ ( $\mathrm{H} 3 \mathrm{~K} 9 \mathrm{me} 3)$ when targeted to the HS2 enhancer of the human beta-globin locus, thereby inhibiting the expression of globin genes ${ }^{83}$.

For activating epigenetic modifications, the catalytic domain of the human acetyltransferase p300 has been fused to dCas9, which is able to increase the level of $\mathrm{H} 3 \mathrm{~K} 27 \mathrm{ac}$ at the enhancer and promoter of targeted genes, resulting in their transcriptional activation ${ }^{84}$. Furthermore, integrating the catalytic domain of histone methyltransferase PRDM9 with dCas9 or zinc finger (ZF) proteins has been shown to increase the level of trimethylated H3K4 (H3K4me3) and reactivates silenced target genes in mammalian cells ${ }^{85}$. The maintenance of the reactivated state, however, is strongly dependent on the DNA methylation status of the $\mathrm{CpG}$ islands at their promoters. For example, gene re-expression achieved by targeted epigenetic editing can be maintained in DNA hypomethylated loci (e.g. PLOD2 in C33a cells), in contrast to transient reactivation observed in hypermethylated loci (e.g. EpCAM in HeLa cells). Stable gene reactivation depends on the presence of methylation marks on histone $\mathrm{H} 3$ lysine 79 (H3K79me), which is required for the stability and maintenance of $\mathrm{H} 3 \mathrm{~K} 4 \mathrm{me} 3$. Epigenetic editing to enrich $\mathrm{H} 3 \mathrm{~K} 4 \mathrm{me} 3$ by dCas9-PRDM9 and H3K79me by dCas9-DOT1L is able to sustain gene reactivation in a hypermethylated locus when DNA methyltransferase is inhibited ${ }^{85}$.

Gene expression can also be modulated by dCas9-based regulation of DNA methylation. Fusion of the catalytic domain of the DNA demethylase TET1 to dCas9 can induce targeted DNA demethylation ${ }^{86-89}$. The dCas9-TET1 fusion can demethylate 30 to $60 \%$ of the $\mathrm{CpG}$ islands at tested promoters, which drives the transcriptional activation of target genes in various cell types including embryonic stem cells, cancer cell lines, fibroblasts, and primary neurons ${ }^{86-89}$. Alternatively, tethering of the full-length or catalytic domain of DNA methyltransferase 3A (DNMT3A) to dCas9 is shown to induce methylation of the $\mathrm{CpG}$ islands at a range of 30 to $50 \%$ of the sgRNA-targeted genomic loci, thus leading to reduced expression of those targeted genes in various cell types ${ }^{86,90,91}$. Interestingly, triple recruitment of DNMT3A, DNMT3L, and KRAB via different fusion constructs is able to achieve up to $100 \%$ of methylation of the $\mathrm{CpG}$ islands and results in stable loss of expression of the targeted genes ${ }^{92}$. Gene silencing mediated by co-recruitment of such epigenetic modifiers is resistant to external transcriptional activation stimuli, for instance dCas9-VP160 or dCas9-p300, but can be reversed by targeted DNA demethylation mediated by dCas9-TET $1^{92}$.

Together, these studies have demonstrated how to utilize dCas9based epigenetic modifiers for locus-specific epigenetic editing in mammalian cells. In the future, it will be intriguing to investigate how epigenetic modifications alter local genomic structure. Meanwhile, further expanding and combining novel epigenetic modifier tools may serve as the key to improve regulatory controls of endogenous gene expression. The dCas9 epigenetic editing toolkit will become a key component for understanding the relationship between chromatin states, gene regulation, and cellular phenotypes.

\section{Multimodal function and multi-dimensional controls of CRISPR-(d)Cas9}

One of CRISPR-dCas9's unique strengths is its ability to regulate the expression of multiple genes in a simultaneous and inducible manner. Novel regulatory approaches that combine Cas 9 or dCas 9 with optogenetics, chemical biology, RNA, and protein engineering have been created to facilitate the dynamic and spatiotemporal control of target genes (Figure 3).

For instance, an optogenetic transcriptional control system can be integrated into CRISPR-dCas $9^{93,94}$. By decoupling dCas9 from its transcriptional effector (e.g. VP64 or p65AD) and fusing each member to a light-inducible heterodimerizing pair of proteins (e.g. CRY-CIB system), effectors can be recruited to dCas9 to activate endogenous genes in a rapid and reversible manner upon exposure to blue light (Figure 3A). Furthermore, CRISPR-dCas 9 can be integrated with small-molecule-mediated transcriptional systems to modulate the expression of targeted genes $^{95}$. One system uses dCas9-VP64 split into two components, which are then fused to rapamycin-binding dimerization domains FK506 binding protein 12 (FKBP) and FKBP rapamycin binding (FRB) (Figure 3B). In the presence of rapamycin, dCas9-VP64 is reassembled and can activate the transcription of multiple genes to a level comparable to that of the full-length dCas9-VP64 in HEK293FT cells. However, transcriptional activation of these genes is irreversible upon withdrawal of rapamycin ${ }^{95}$. In another study, direct evolution of Cas9 using randomized insertional mutagenesis revealed hotspots for incorporating small synthetic protein domains into Cas9 without compromising the enzyme's 
A

Optogenetic control of CRISPRa

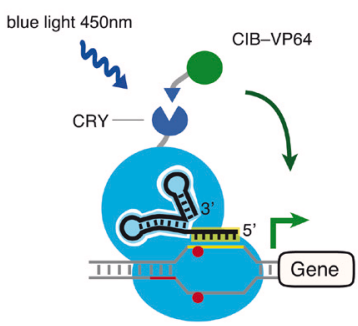

dCas9-CRY::CIB-VP64

\section{B}

\section{Control of CRISPRa/i by chemically induced hetereodimerization}

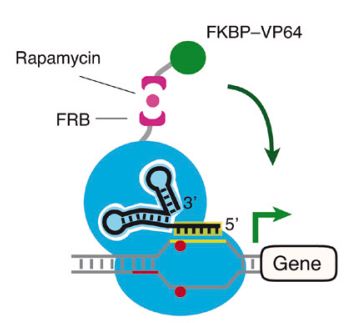

dCas9-FRB::FKBP-VP64

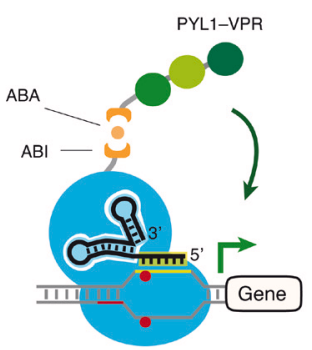

dCas9-ABI::PYL1-VPR

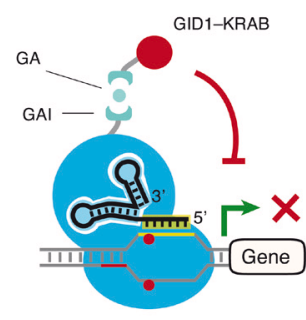

dCas9-GAI::GID1-KRAB

C

Orthogonal CRISPRa/i with scRNA

D

\section{Orthogonal CRISPRa with degrons}

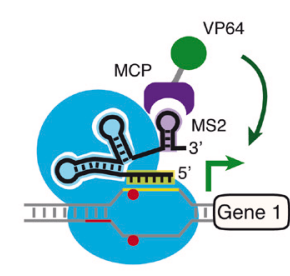

sgRNA-MS2::MCP-VP64

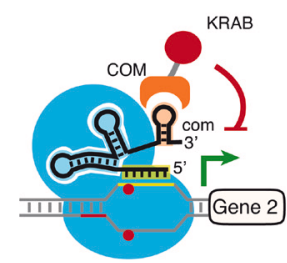

sgRNA-COm::COM-KRAB

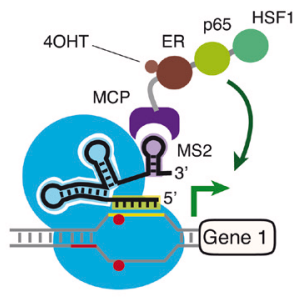

4OHT::MCP-ER-p65-HSF1

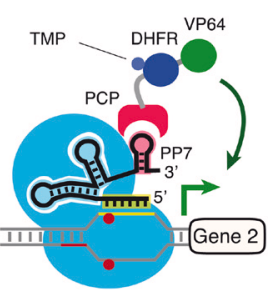

TMP::PCP-DHFR-VP64

\section{E}

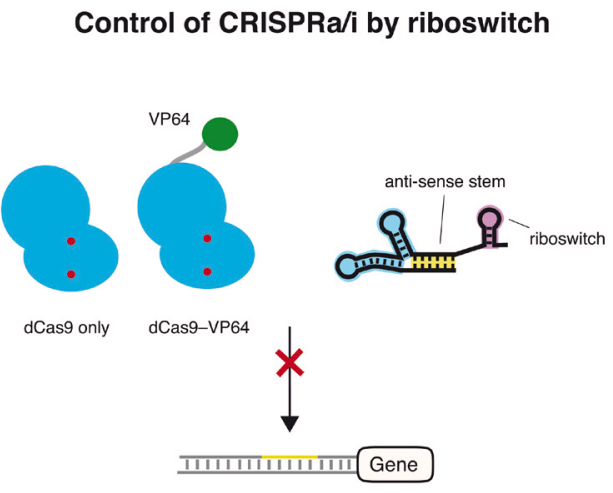

Guide region of the sgRNA is paired with anti-sense stem and cannot bind to its target DNA in the absence of signal

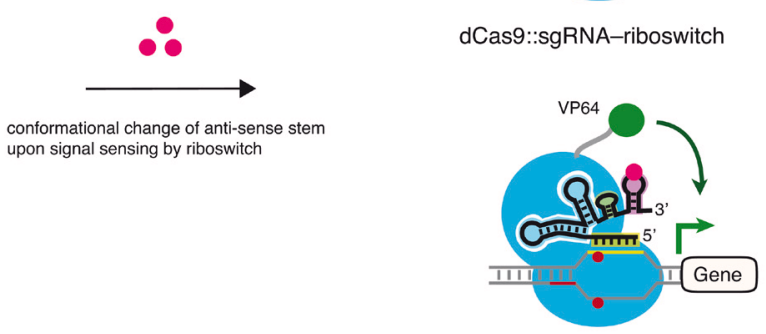

dCas9-VP64::sgRNA-riboswitch

Figure 3. Synthetic approaches for complex and precise control of clustered regularly interspaced short palindromic repeats (CRISPR)-nuclease-deficient CRISPR-associated 9 (dCas9) systems. A. Control of CRISPR-dCas9 systems by light-inducible heterodimerization proteins. dCas9 and transcriptional effector (e.g. four copies of Herpes simplex viral protein 16 [VP64]) can be decoupled and fused to CRY and CIB, respectively. Upon sensing blue light, VP64 is recruited to dCas9 to activate gene expression. B. CRISPR-dCas9 systems can be rendered chemically controlled. Small-molecule-induced heterodimerization domains (e.g. FRB::FKBP, ABI::PYL1, and GAl::GID1) are introduced to dCas9-effector split systems for transcriptional controls. Binding of corresponding chemical (e.g. rapamycin, abscisic acid $[\mathrm{ABA}]$, or gibberellin $[\mathrm{GA}]$ ) induces gene regulation by CRISPR-dCas9. C. Simultaneous gene activation and repression using a scaffold RNA (scRNA) system. A hybrid RNA consisting of an sgRNA and an RNA aptamer (e.g. MS2, com, PP7) is able to recruit the cognate RNA-binding protein (e.g. MCP, COM, PCP) tethered to either an activator (e.g. VP64) or a repressor (e.g. Krüppel-associated box [KRAB]). D. CRISPR-dCas9 systems can be regulated by protein destabilization domains. Structurally unstable protein domains such as estrogen receptor (ER) or the dihydrofolate reductase (DHFR) are fused to a chimeric protein consisting of an aptamer-binding protein (e.g. MCP or PCP) and a transcriptional activator (e.g. p65-HSF1 or VP64). These unfolded and destabilized domains increase fusion protein turnover by rapid proteasome-mediated degradation. Small molecules can bind and stabilize those domains (e.g. binding of 4OHT [4-hydroxytamoxifen] stabilizes ER, and binding of TMP [trimethoprim] stabilizes DHFR), allowing the control of gene expression. E. Control of CRISPR-dCas9 systems by RNA switchable devices. The single guide RNA (sgRNA) can be engineered to become a biosensor by fusing it with signal-responsive RNA aptamers. In the absence of certain signals, the guide region of the sgRNA pairs with the antisense stem and therefore cannot bind to its target DNA. Upon sensing specific signals by the RNA aptamers, a conformational change allows the guide region of the sgRNA to bring the dCas9 or dCas9-effector complex to the target DNA site, thereby altering gene expression. 
RNA-guided DNA-binding activity. Insertion of the ligandbinding domain of human estrogen receptor- $\alpha$ renders dCas9 allosterically responsive to 4-hydroxytamoxifen (4OHT), thereby permitting the precise regulation of CRISPRi activity by this drug $^{96}$.

In order to enable simultaneous editing and/or control of multiple genes within the same cell population, Cas9 orthologs have been characterized and employed ${ }^{97-99}$. For instance, Cas9 from Streptococcus pyogenes and Neisseria meningitidis displays distinct patterns in its recognition of target sequences and therefore can mediate independent transcriptional repression and nuclease activity ${ }^{97}$. Furthermore, orthogonal dCas 9 regulators that utilize multiple chemically induced dimerization systems have been developed to allow the temporal control of gene regulation ${ }^{100,101}$. In a screen of chemical- and light-inducible heterodimerization systems to control the association of dCas9 with effectors, the potent chemical inducers abscisic acid (ABA) and gibberellin (GA) were shown to mediate efficient gene activation and repression in mammalian cells ${ }^{100}$ (Figure 3B). Fusion of ABA and GA inducer systems with orthogonal dCas9 regulators can independently control the expression of different genes within the same cell. Moreover, these systems can be used to devise basic Boolean logic-gated dCas9 operators to achieve orthogonal and multiplexed transcriptional modulation ${ }^{100}$. Separately, another study reported CRISPR-dCas9 activators that can be chemically induced with rapamycin and GA-mediated dimerization systems to activate endogenous human genes ${ }^{101}$.

In addition to its use in protein engineering, the sgRNA can also be engineered as a scaffold RNA (scRNA) to expand the utility of CRISPR-dCas9 systems (Figure 3C). The scRNA, created by appending protein-binding RNA aptamers to the sgRNA, can serve as an adaptor to recruit the cognate RNA-binding proteins (RBPs) that fused with the transcriptional repressor or activator ${ }^{73,102}$. This design allows for simultaneous gene activation and repression within the same cell when orthogonal scRNA aptamer-RBP pairs are used for different gene targets. Furthermore, RBPs can be modified with small-molecule-mediated protein degradation domains (degrons) to offer fine-tuned control of the targeted gene's regulation $^{103}$ (Figure 3D). Additionally, by coupling riboswitches (i.e. switchable RNA devices that recognize specific stimuli) with sgRNA, the dCas9-sgRNA complex is able to function as a type of "signal conductor" that can regulate the transcription of endogenous genes in response to external or internal riboswitchresponsive signals ${ }^{104}$ (Figure $3 \mathrm{E}$ ). dCas9-based signal conductors can also be applied for rewiring signaling pathways by devising artificial links that couple different signaling components. These systems can also be used to reprogram the fate of cancer cells by converging oncogenic signaling into an anti-oncogenic pathway ${ }^{104}$. More sophisticated circuits with layered regulatory mechanisms have been designed to control Cas9-based transcriptional repression machinery in mammalian cells ${ }^{105}$.

Approaches such as using split Cas9 variants ${ }^{95,106-108}$, transient delivery of Cas9:sgRNA ribonucleotide protein complexes (RNPs) $)^{109-111}$, engineered allosteric protein or RNA switches, and novel optogenetic or chemogenetic systems have also been applied to the CRISPR-Cas9 method for gene editing for the purpose of generating conditional gene knockouts and for reducing the levels of off-target effects ${ }^{95,96,112-119}$. Expanding these approaches to the CRISPR-dCas 9 systems will likely result in new features of regulation for dCas9-based control of gene expression.

\section{CRISPR-dCas9 systems versus previous existing gene regulation techniques}

There are several existing methods for gene repression, gene activation, and epigenome modification. For example, techniques based on RNA interference (RNAi), which consists of small interfering RNAs (siRNA) or short hairpin RNAs (shRNA), allow for sequence-specific repression of endogenous genes of interest in eukaryotic organisms. This gene silencing effect is mediated by transcript-specific degradation due to Watson-Crick base-pairing between mRNA and siRNA or shRNA (for reviews, see 120-123). On the other hand, the overexpression of genes of interest can be achieved by cloning open reading frames (ORFs) or cDNAs followed by vector-mediated gene transfer ${ }^{124}$. A number of genometargeting technologies such as ZF proteins ${ }^{125-128}$ or transcription activator-like effector nucleases (TALENs) ${ }^{128-135}$ have been devised for gene-editing applications, which are achieved by fusing endonuclease catalytic domains with modular DNA-binding proteins to induce DSBs at the targeted genomic loci. Targeting strategies based on protein-DNA interaction using ZF and TALENs can also be applied for gene regulation or epigenome medication when coupled to the transcriptional repressor, activator, or epigenetic modifiers mentioned earlier. Compared to these targeting techniques, CRISPR-dCas9-based gene regulation systems are easier to design, highly specific and efficient, cost effective, and well-suited for high-throughput and multiplexed gene regulation across many cell types and organisms. Nevertheless, limitations do exist for CRISPR-dCas9-based gene regulation systems depending on the application of interest. For instance, RNAi-mediated gene silencing and/or ORF overexpression techniques can be applied to study the function of gene splice variants. Comparisons of CRISPRi/a versus existing common gene repression or activation systems are summarized in Table 1 and Table 2. 


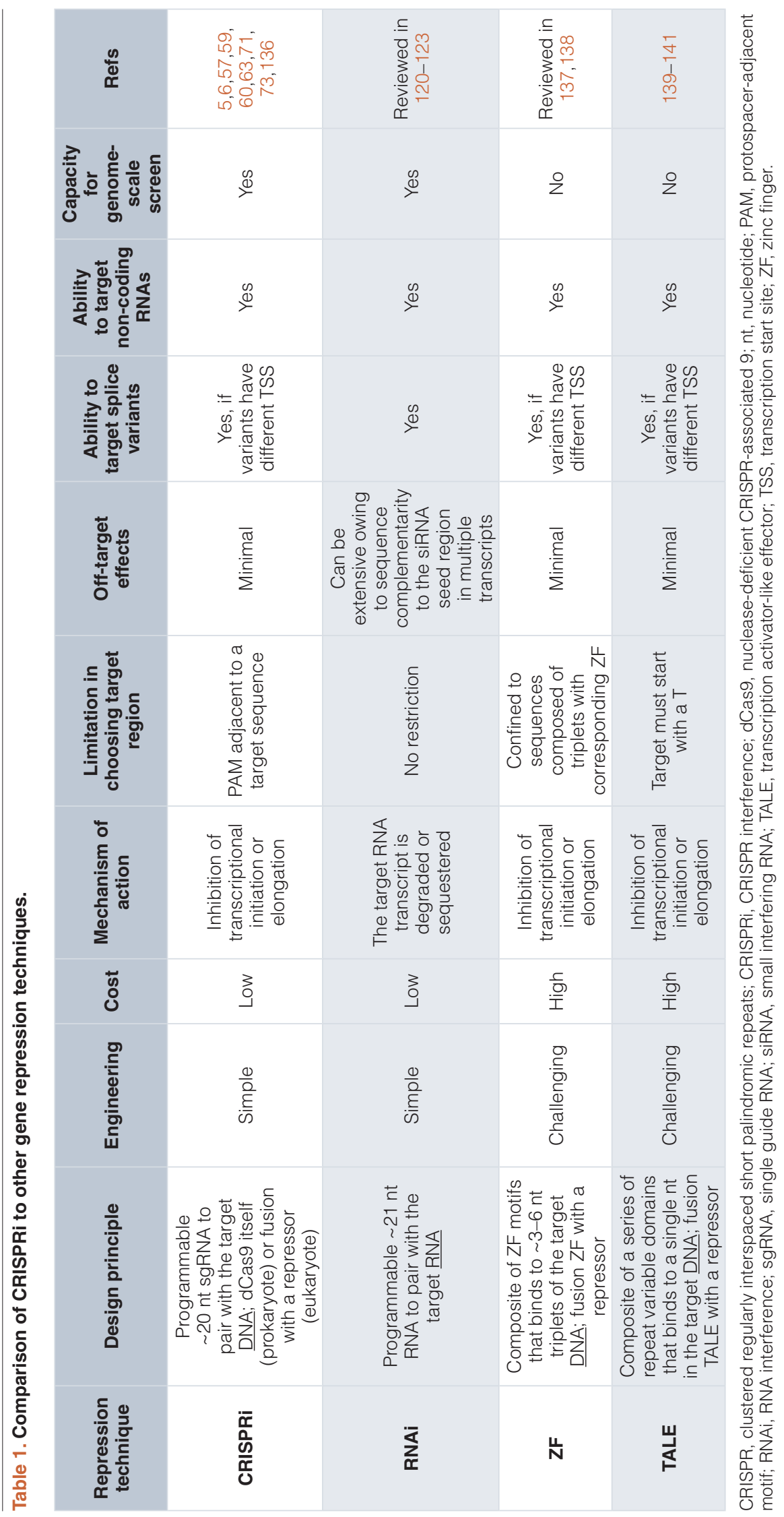




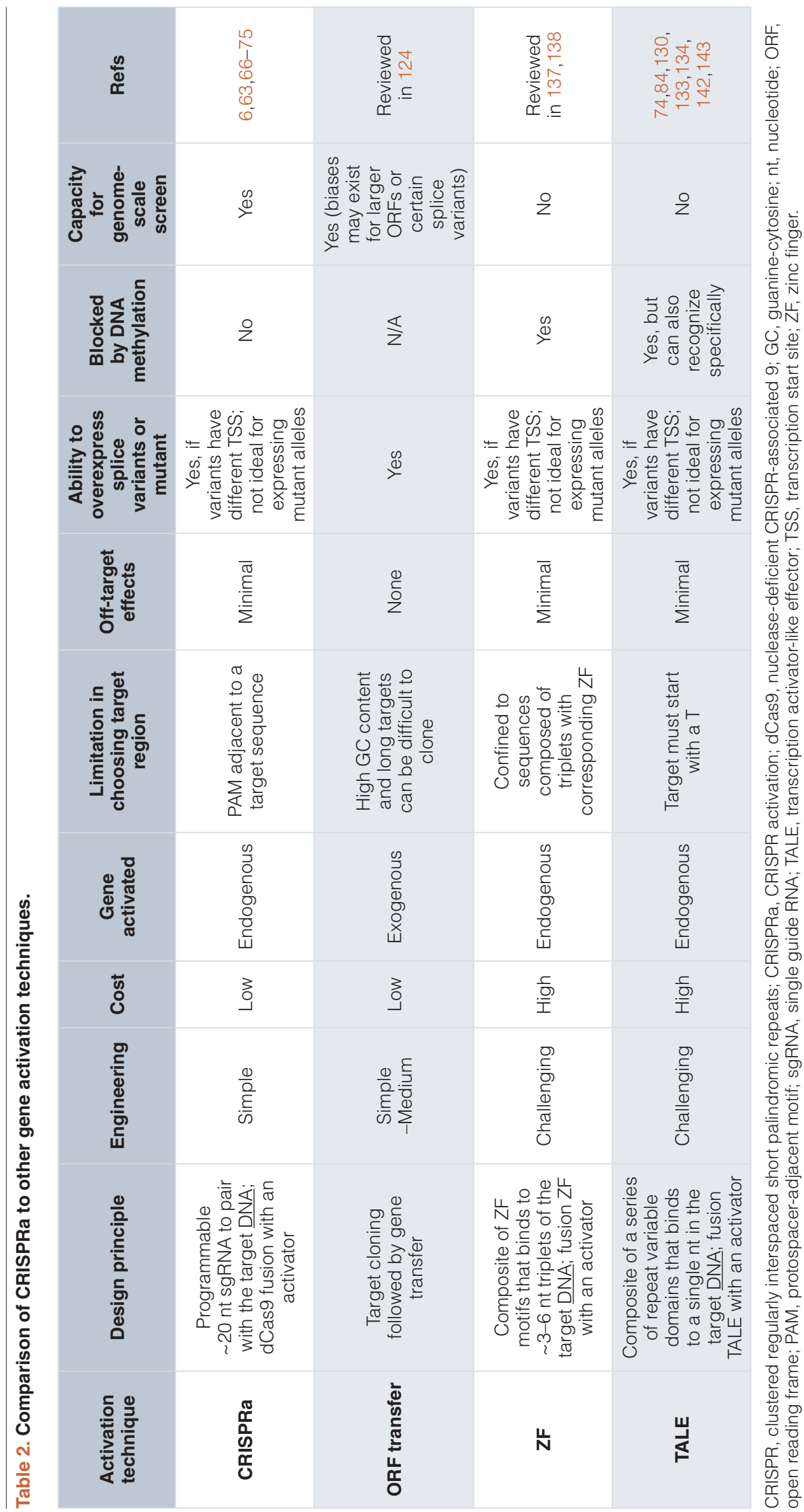




\section{Conclusions}

The discovery of CRISPR-Cas as an RNA-guided DNA endonuclease system has inspired the development of revolutionary gene editing tools that allow for studying the function of the genome on a cellular and organismic level. In addition to the complete loss-of-function perturbations made possible by nuclease Cas9, the development of dCas9-based CRISPRi and CRISPRa technologies has enabled reversible, multiplexed, and loss- and/or gain-of-function studies of genes of interest. Furthermore, the ability to site-specifically target chromatin modifiers fused to dCas9 will contribute to our understanding of epigenomic regulation. Genome-wide screening based on CRISPR-dCas9 systems are helping to untangle complex biological processes and identify key genetic players of diseases ${ }^{66,75}$. Integrating the dCas9 transcriptional or epigenetic tools with tools based on Cas9 gene editing, RNAi tools on the RNA level, and other molecular tools will undoubtedly constitute the next-generation toolkit for controlling inheritance and the central dogma. We imagine the diversity, lasticity, and flexibility of CRISPR-dCas9 systems will allow researchers to develop more advanced genome-engineering tools for a wide range of applications in basic research and translational medicine.

\section{Competing interests}

The authors declare that they have no competing interests.

\section{Grant information}

This work was supported by DP5 OD017887, Pew Scholar Fellowship, and Sloan Research Fellowship (L.S.Q).

The funders had no role in study design, data collection and analysis, decision to publish, or preparation of the manuscript.

\section{Acknowledgements}

The authors thank the members of the Qi lab (Wang H. and La Russa M.) for advice and helpful discussions. L.S.Q. acknowledges support from the NIH Office of the Director (OD), the National Institute of Dental \& Craniofacial Research (NIDCR), Pew Charitable Trusts, and the Alfred P. Sloan Foundation.
1. Maurano MT, Humbert R, Rynes E, et al:: Systematic localization of common disease-associated variation in regulatory DNA. Science. 2012; 337(6099): $1190-5$.

PubMed Abstract | Publisher Full Text | Free Full Text

2. F Emilsson V, Thorleifsson G, Zhang B, et al:: Genetics of gene expression and its effect on disease. Nature. 2008; 452(7186): 423-8. PubMed Abstract | Publisher Full Text | F1000 Recommendation

3. Feinberg AP, Koldobskiy MA, Göndör A: Epigenetic modulators, modifiers and mediators in cancer aetiology and progression. Nat Rev Genet. 2016; 17(5): 284-99.

PubMed Abstract | Publisher Full Text | Free Full Text

4. Crick F: Central dogma of molecular biology. Nature. 1970; 227(5258): 561-3 PubMed Abstract | Publisher Full Text

5. F Gasiunas G, Barrangou R, Horvath $P$, et al.: Cas9-crRNA ribonucleoprotein complex mediates specific DNA cleavage for adaptive immunity in bacteria. Proc Natl Acad Sci U S A. 2012; 109(39): E2579-86. PubMed Abstract | Publisher Full Text | Free Full Text | F1000 Recommendation

6. $\quad \mathrm{F}$ Jinek $\mathrm{M}$, Chylinski K, Fonfara I, et al:: A programmable dual-RNA-guided DNA endonuclease in adaptive bacterial immunity. Science. 2012; 337(6096): $816-21$.

PubMed Abstract | Publisher Full Text | F1000 Recommendation

7. F Sapranauskas R, Gasiunas G, Fremaux C, et al.: The Streptococcus thermophilus CRISPR/Cas system provides immunity in Escherichia coli. Nucleic Acids Res. 2011; 39(21): 9275-82.

PubMed Abstract | Publisher Full Text | Free Full Text | F1000 Recommendation

8. F Garneau JE, Dupuis MÈ, Villion M, et al:: The CRISPR/Cas bacterial immune system cleaves bacteriophage and plasmid DNA. Nature. 2010; 468(7320): 67-71. PubMed Abstract | Publisher Full Text | F1000 Recommendation

9. $\quad \mathrm{F}$ Barrangou $\mathrm{R}$, Fremaux $\mathrm{C}$, Deveau $\mathrm{H}$, et al.: CRISPR provides acquired resistance against viruses in prokaryotes. Science. 2007; 315(5819): 1709-12. PubMed Abstract | Publisher Full Text | F1000 Recommendation

10. F Deltcheva E, Chylinski K, Sharma CM, et al:: CRISPR RNA maturation by trans-encoded small RNA and host factor RNase III. Nature. 2011; 471(7340): 602-7.

PubMed Abstract | Publisher Full Text | Free Full Text | F1000 Recommendation

11. F Brouns SJ, Jore MM, Lundgren M, et al.: Small CRISPR RNAs guide antiviral defense in prokaryotes. Science. 2008; 321(5891): 960-4. PubMed Abstract | Publisher Full Text | F1000 Recommendation

12. F Pourcel C, Salvignol G, Vergnaud G: CRISPR elements in Yersinia pestis acquire new repeats by preferential uptake of bacteriophage DNA, and provide additional tools for evolutionary studies. Microbiology. 2005; 151(Pt 3): 653-63. PubMed Abstract | Publisher Full Text | F1000 Recommendation

13. F Shmakov S, Abudayyeh OO, Makarova KS, et al.: Discovery and Functional Characterization of Diverse Class 2 CRISPR-Cas Systems. Mol Cell. 2015; 60(3): 385-97.

PubMed Abstract | Publisher Full Text | Free Full Text | F1000 Recommendation

14. F Rath $\mathrm{D}$, Amlinger $\mathrm{L}$, Rath $\mathrm{A}$, et al:: The CRISPR-Cas immune system biology, mechanisms and applications. Biochimie. 2015; 117: 119-28. PubMed Abstract | Publisher Full Text | F1000 Recommendation

15. F Mojica FJ, Díez-Villaseñor C, García-Martínez J, et al:: Intervening sequences of regularly spaced prokaryotic repeats derive from foreign genetic elements. $J \mathrm{Mol}$ Evol. 2005; 60(2): 174-82.

PubMed Abstract | Publisher Full Text | F1000 Recommendation

16. F Bolotin A, Quinquis B, Sorokin A, et al:: Clustered regularly interspaced short palindrome repeats (CRISPRs) have spacers of extrachromosomal origin. Microbiology. 2005; 151(Pt 8): 2551-61. PubMed Abstract | Publisher Full Text | F1000 Recommendation

17. F Marraffini LA, Sontheimer EJ: CRISPR interference limits horizontal gene transfer in staphylococci by targeting DNA. Science. 2008; 322(5909): 1843-5. PubMed Abstract | Publisher Full Text | Free Full Text | F1000 Recommendation

18. F Makarova KS, Wolf $\mathrm{YI}$, Alkhnbashi OS, et al.: An updated evolutionary classification of CRISPR-Cas systems. Nat Rev Microbiol. 2015; 13(11): 722-36. PubMed Abstract | Publisher Full Text | Free Full Text | F1000 Recommendation

19. F Shmakov S, Smargon A, Scott D, et al.: Diversity and evolution of class 2 CRISPR-Cas systems. Nat Rev Microbiol. 2017; 15(3): 169-82. PubMed Abstract | Publisher Full Text | F1000 Recommendation

20. F Makarova KS, Zhang F, Koonin EV: SnapShot: Class 2 CRISPR-Cas Systems. Cell. 2017; 168(1-2): 328-328.e1.

PubMed Abstract | Publisher Full Text | F1000 Recommendation

21. Zetsche B, Gootenberg JS, Abudayyeh OO, et al:: Cpf1 is a single RNA-guided endonuclease of a class 2 CRISPR-Cas system. Cell. 2015; 163(3): 759-71. PubMed Abstract | Publisher Full Text | Free Full Text

22. F Jiang W, Bikard D, Cox D, et al:: RNA-guided editing of bacterial genomes using CRISPR-Cas systems. Nat Biotechnol. 2013; 31(3): 233-9. PubMed Abstract | Publisher Full Text | Free Full Text | F1000 Recommendation

23. Lim MY, LaMonte G, Lee MC, et al: UDP-galactose and acetyl-CoA transporters as Plasmodium multidrug resistance genes. Nat Microbiol. 2016; 16166. PubMed Abstract | Publisher Full Text

24. Blondel CJ, Park JS, Hubbard TP, et al.: CRISPR/Cas9 Screens Reveal Requirements for Host Cell Sulfation and Fucosylation in Bacterial Type III 
Secretion System-Mediated Cytotoxicity. Cell Host Microbe. 2016; 20(2): 226-37. PubMed Abstract | Publisher Full Text | Free Full Text

25. F Wang $\mathrm{Y}$, Cobb RE, Zhao H: High-Efficiency Genome Editing of Streptomyces Species by an Engineered CRISPR/Cas System. Methods Enzymol. 2016; 575: 271-84.

PubMed Abstract | Publisher Full Text | F1000 Recommendation

26. F DiCarlo JE, Norville JE, Mali $P$, et al:: Genome engineering in Saccharomyces cerevisiae using CRISPR-Cas systems. Nucleic Acids Res. 2013; 41(7): 4336-43.

PubMed Abstract | Publisher Full Text | Free Full Text | F1000 Recommendation

27. F Reider Apel A, d'Espaux L, Wehrs M, et al:: A Cas9-based toolkit to program gene expression in Saccharomyces cerevisiae. Nucleic Acids Res. 2017; 45(1): 496-508.

PubMed Abstract | Publisher Full Text | Free Full Text | F1000 Recommendation

28. Laughery MF, Hunter T, Brown A, et al:: New vectors for simple and streamlined CRISPR-Cas9 genome editing in Saccharomyces cerevisiae. Yeast. 2015; 32(12): 711-20.

PubMed Abstract | Publisher Full Text | Free Full Text

29. Bao Z, Xiao H, Liang J, et al:: Homology-integrated CRISPR-Cas (HI-CRISPR) system for one-step multigene disruption in Saccharomyces cerevisiae. ACS Synth Biol. 2015; 4(5): 585-94.

PubMed Abstract | Publisher Full Text

30. Miyanari $\mathrm{Y}$, Ziegler-Birling $\mathrm{C}$, Torres-Padilla ME: Live visualization of chromatin dynamics with fluorescent TALEs. Nat Struct Mol Biol. 2013; 20(11): 1321-4. PubMed Abstract | Publisher Full Text

31. Nekrasov V, Staskawicz B, Weigel D, et al:: Targeted mutagenesis in the model plant Nicotiana benthamiana using Cas9 RNA-guided endonuclease. Nat Biotechnol. 2013; 31(8): 691-3.

PubMed Abstract | Publisher Full Text

32. Feng Z, Zhang B, Ding W, et al.: Efficient genome editing in plants using a CRISPR/Cas system. Cell Res. 2013; 23(10): 1229-32. PubMed Abstract | Publisher Full Text | Free Full Text

33. Xie $\mathrm{K}$, Yang Y: RNA-guided genome editing in plants using a CRISPR-Cas system. Mol Plant. 2013; 6(6): 1975-83.

PubMed Abstract | Publisher Full Text

34. Čermák T, Baltes NJ, Čegan R, et al.: High-frequency, precise modification of the tomato genome. Genome Biol. 2015; 16: 232 . PubMed Abstract | Publisher Full Text | Free Full Text

35. Feng $\mathrm{Z}, \mathrm{Mao} \mathrm{Y}, \mathrm{Xu} \mathrm{N}$, et al:: Multigeneration analysis reveals the inheritance, specificity, and patterns of CRISPR/Cas-induced gene modifications in Arabidopsis. Proc Natl Acad Sci U S A. 2014; 111(12): 4632-7. PubMed Abstract | Publisher Full Text | Free Full Text

36. Shan $\mathrm{Q}$, Wang $\mathrm{Y}, \mathrm{Li} \mathrm{J}$, et al.: Genome editing in rice and wheat using the CRISPR/Cas system. Nat Protoc. 2014; 9(10): 2395-410. PubMed Abstract | Publisher Full Text

37. F Svitashev S, Schwartz C, Lenderts B, et al:: Genome editing in maize directed by CRISPR-Cas9 ribonucleoprotein complexes. Nat Commun. 2016; 7 : 13274.

PubMed Abstract | Publisher Full Text | Free Full Text | F1000 Recommendation

38. F Woo JW, Kim J, Kwon SI, et al.: DNA-free genome editing in plants with preassembled CRISPR-Cas9 ribonucleoproteins. Nat Biotechnol. 2015; 33(11): $1162-4$.

PubMed Abstract | Publisher Full Text | F1000 Recommendation

39. Zhang $Y$, Liang $Z$, Zong $Y$, et al.: Efficient and transgene-free genome editing in wheat through transient expression of CRISPR/Cas9 DNA or RNA. Nat Commun. 2016; 7: 12617.

PubMed Abstract | Publisher Full Text | Free Full Text

40. Zhou H, Liu B, Weeks DP, et al:: Large chromosomal deletions and heritable small genetic changes induced by CRISPR/Cas9 in rice. Nucleic Acids Res. 2014; 42(17): 10903-14.

PubMed Abstract | Publisher Full Text | Free Full Text

41. $\mathrm{F}$ Wang $\mathrm{H}$, Yang $\mathrm{H}$, Shivalila $\mathrm{CS}$, et al:: One-step generation of mice carrying mutations in multiple genes by CRISPR/Cas-mediated genome engineering. Cell. 2013; 153(4): 910-8.

PubMed Abstract | Publisher Full Text | Free Full Text | F1000 Recommendation

42. Hwang WY, Fu Y, Reyon D, et al:: Efficient genome editing in zebrafish using a CRISPR-Cas system. Nat Biotechnol. 2013: 31(3): 227-9.

PubMed Abstract | Publisher Full Text | Free Full Text

43. F Lv Q, Yuan L, Deng J, et al.: Efficient Generation of Myostatin Gene Mutated Rabbit by CRISPR/Cas9. Sci Rep. 2016; 6: 25029.

PubMed Abstract | Publisher Full Text | Free Full Text | F1000 Recommendation

44. Wang X, Yu H, Lei A, et al: Generation of gene-modified goats targeting MSTN and FGF5 via zygote injection of CRISPR/Cas9 system. Sci Rep. 2015; 5: 13878. PubMed Abstract | Publisher Full Text | Free Full Text

45. Li W, Teng F, Li T, et al:: Simultaneous generation and germline transmission of multiple gene mutations in rat using CRISPR-Cas systems. Nat Biotechnol. 2013; 31(8): 684-6.

PubMed Abstract | Publisher Full Text

46. Wang K, Ouyang H, Xie Z, et al:: Efficient Generation of Myostatin Mutations in Pigs Using the CRISPR/Cas9 System. Sci Rep. 2015; 5: 16623.

PubMed Abstract | Publisher Full Text | Free Full Text
47. Mojica FJ, Díez-Villaseñor C, Garcia-Martinez J, et al:: Short motif sequences determine the targets of the prokaryotic CRISPR defence system. Microbiology. 2009; 155(3): 733-40.

PubMed Abstract | Publisher Full Text

48. F Cong L, Ran FA, Cox D, et al:: Multiplex genome engineering using CRISPR/Cas systems. Science. 2013; 339(6121): 819-23. PubMed Abstract | Publisher Full Text | Free Full Text | F1000 Recommendation

49. $\mathrm{F}$ Mali $\mathrm{P}$, Yang L, Esvelt KM, et al:: RNA-guided human genome engineering via Cas9. Science. 2013; 339(6121): 823-6.

PubMed Abstract | Publisher Full Text | Free Full Text | F1000 Recommendation

50. Cho SW, Kim S, Kim JM, et al.: Targeted genome engineering in human cells with the Cas9 RNA-guided endonuclease. Nat Biotechnol. 2013; 31(3): 230-2. PubMed Abstract | Publisher Full Text

51. F Jinek M, East A, Cheng A, et al.: RNA-programmed genome editing in human cells. eLife. 2013; 2: e00471.

PubMed Abstract | Publisher Full Text | Free Full Text | F1000 Recommendation

52. F Wright AV, Nuñez JK, Doudna JA: Biology and Applications of CRISPR Systems: Harnessing Nature's Toolbox for Genome Engineering. Cell. 2016 164(1-2): 29-44.

PubMed Abstract | Publisher Full Text | F1000 Recommendation

53. Wang H, La Russa M, Qi LS: CRISPR/Cas9 in Genome Editing and Beyond. Annu Rev Biochem. 2016; 85: 227-64.

PubMed Abstract | Publisher Full Text

54. F Komor AC, Badran AH, Liu DR: CRISPR-Based Technologies for the Manipulation of Eukaryotic Genomes. Cell. 2017; 168(1-2): 20-36. PubMed Abstract | Publisher Full Text | Free Full Text | F1000 Recommendation

55. Dominguez AA, Lim WA, Qi LS: Beyond editing: repurposing CRISPR-Cas9 for precision genome regulation and interrogation. Nat Rev Mol Cell Biol. 2016; 17(1): $5-15$

PubMed Abstract | Publisher Full Text | Free Full Text

56. La Russa MF, Qi LS: The New State of the Art: Cas9 for Gene Activation and Repression. Mol Cell Biol. 2015; 35(22): 3800-9. PubMed Abstract | Publisher Full Text | Free Full Text

57. F Qi LS, Larson MH, Gilbert LA, et al.: Repurposing CRISPR as an RNA-guided platform for sequence-specific control of gene expression. Cell. 2013; 152(5): 1173-83.

PubMed Abstract | Publisher Full Text | Free Full Text | F1000 Recommendation

58. Jiang F, Doudna JA: CRISPR-Cas9 Structures and Mechanisms. Annu Rev Biophys. 2017.

PubMed Abstract | Publisher Full Text

59. F Bikard D, Jiang W, Samai $\mathrm{P}$, et al:: Programmable repression and activation of bacterial gene expression using an engineered CRISPR-Cas system. Nucleic Acids Res. 2013; 41(15): 7429-37.

PubMed Abstract | Publisher Full Text | Free Full Text | F1000 Recommendation

60. Larson MH, Gilbert LA, Wang X, et al.: CRISPR interference (CRISPRi) for sequence-specific control of gene expression. Nat Protoc. 2013; 8(11): 2180-96. PubMed Abstract | Publisher Full Text | Free Full Text

61. Ji W, Lee D, Wong E, et al:: Specific gene repression by CRISPRi system transferred through bacterial conjugation. ACS Synth Biol. 2014; 3(12): 929-31. PubMed Abstract | Publisher Full Text | Free Full Text

62. F Peters JM, Colavin A, Shi H, et al:: A Comprehensive, CRISPR-based Functional Analysis of Essential Genes in Bacteria. Cell. 2016; 165(6): 1493-506. PubMed Abstract | Publisher Full Text | Free Full Text | F1000 Recommendation

63. F Gilbert LA, Larson MH, Morsut L, et al:: CRISPR-mediated modular RNAguided regulation of transcription in eukaryotes. Cell. 2013; 154(2): 442-51. PubMed Abstract | Publisher Full Text | Free Full Text | F1000 Recommendation

64. Lawhorn IE, Ferreira JP, Wang CL: Evaluation of sgRNA target sites for CRISPRmediated repression of TP53. PLOS One. 2014; 9(11): e113232. PubMed Abstract | Publisher Full Text | Free Full Text

65. F Konermann S, Brigham MD, Trevino AE, et al:: Optical control of mammalian endogenous transcription and epigenetic states. Nature. 2013; 500(7463): 472-6. PubMed Abstract | Publisher Full Text | Free Full Text | F1000 Recommendation

66. F Gilbert LA, Horlbeck MA, Adamson B, et al:: Genome-Scale CRISPR-Mediated Control of Gene Repression and Activation. Cell. 2014; 159(3): 647-61. PubMed Abstract | Publisher Full Text | Free Full Text | F1000 Recommendation

67. Cheng AW, Wang $\mathrm{H}$, Yang $\mathrm{H}$, et al:: Multiplexed activation of endogenous genes by CRISPR-on, an RNA-guided transcriptional activator system. Cell Res. 2013; 23(10): 1163-71.

PubMed Abstract | Publisher Full Text | Free Full Text

68. Gao X, Tsang JC, Gaba F, et al:: Comparison of TALE designer transcription factors and the CRISPR/dCas9 in regulation of gene expression by targeting enhancers. Nucleic Acids Res. 2014; 42(20): e155. PubMed Abstract | Publisher Full Text | Free Full Text

69. Mali P, Aach J, Stranges PB, et al.: CAS9 transcriptional activators for target specificity screening and paired nickases for cooperative genome engineering. Nat Biotechnol. 2013; 31(9): 833-8. PubMed Abstract | Publisher Full Text | Free Full Text

70. Maeder ML, Linder SJ, Cascio VM, et al.: CRISPR RNA-guided activation of endogenous human genes. Nat Methods. 2013; 10(10): 977-9. PubMed Abstract | Publisher Full Text | Free Full Text 
71. Perez-Pinera P, Kocak DD, Vockley CM, et al.: RNA-guided gene activation by CRISPR-Cas9-based transcription factors. Nat Methods. 2013; 10(10): 973-6. PubMed Abstract | Publisher Full Text | Free Full Text

72. Tanenbaum ME, Gilbert LA, Qi LS, et al:: A protein-tagging system for signal amplification in gene expression and fluorescence imaging. Cell. 2014; 159(3) $635-46$

PubMed Abstract | Publisher Full Text | Free Full Text

73. F Zalatan JG, Lee ME, Almeida R, et al.: Engineering complex synthetic transcriptional programs with CRISPR RNA scaffolds. Cell. 2015; 160(1-2): 339-50.

PubMed Abstract | Publisher Full Text | Free Full Text | F1000 Recommendation

74. F Chavez A, Scheiman J, Vora S, et al.: Highly efficient Cas9-mediated transcriptional programming. Nat Methods. 2015; 12(4): 326-8.

PubMed Abstract | Publisher Full Text | Free Full Text | F1000 Recommendation

75. F Konermann S, Brigham MD, Trevino AE, et al: Genome-scale transcriptional activation by an engineered CRISPR-Cas9 complex. Nature. 2015; 517(7536): 583-8.

PubMed Abstract | Publisher Full Text | Free Full Text | F1000 Recommendation

76. F Chavez A, Tuttle M, Pruitt BW, et al.: Comparison of Cas9 activators in multiple species. Nat Methods. 2016; 13(7): 563-7.

PubMed Abstract | Publisher Full Text | Free Full Text | F1000 Recommendation

77. Bannister AJ, Kouzarides T: Regulation of chromatin by histone modifications. Cell Res. 2011; 21(3): 381-95.

PubMed Abstract | Publisher Full Text | Free Full Text

78. Cedar $\mathrm{H}$, Bergman $\mathrm{Y}$ : Linking DNA methylation and histone modification: patterns and paradigms. Nat Rev Genet. 2009; 10(5): 295-304. PubMed Abstract | Publisher Full Text

79. F Consortium EP: An integrated encyclopedia of DNA elements in the human genome. Nature. 2012; 489(7414): 57-74

PubMed Abstract | Publisher Full Text | Free Full Text | F1000 Recommendation

80. F Kundaje A, Meuleman W, Ernst J, et al.: Integrative analysis of 111 reference human epigenomes. Nature. 2015; 518(7539): 317-30.

PubMed Abstract | Publisher Full Text | Free Full Text | F1000 Recommendation

81. Zhou VW, Goren A, Bernstein BE: Charting histone modifications and the functional organization of mammalian genomes. Nat Rev Genet. 2011; 12(1) 7-18.

PubMed Abstract | Publisher Full Text

82. F Kearns NA, Pham H, Tabak B, et al:: Functional annotation of native enhancers with a Cas9-histone demethylase fusion. Nat Methods. 2015; 12(5): 401-3.

PubMed Abstract | Publisher Full Text | Free Full Text | F1000 Recommendation

83. F Thakore PI, D'Ippolito AM, Song L, et al:: Highly specific epigenome editing by CRISPR-Cas 9 repressors for silencing of distal regulatory elements. Nat Methods. 2015; 12(12): 1143-9.

PubMed Abstract | Publisher Full Text | Free Full Text | F1000 Recommendation

84. F Hilton IB, D'Ippolito AM, Vockley CM, et al.: Epigenome editing by a CRISPRCas9-based acetyltransferase activates genes from promoters and enhancers. Nat Biotechnol. 2015; 33(5): 510-7.

PubMed Abstract | Publisher Full Text | Free Full Text | F1000 Recommendation

85. F Cano-Rodriguez D, Gjaltema RA, Jilderda LJ, et al.: Writing of H3K4Me3 overcomes epigenetic silencing in a sustained but context-dependent manner. Nat Commun. 2016; 7: 12284.

PubMed Abstract | Publisher Full Text | Free Full Text | F1000 Recommendation

86. F Liu XS, Wu H, Ji X, et al:: Editing DNA Methylation in the Mammalian Genome. Cell. 2016; 167(1): 233-247.e17.

PubMed Abstract | Publisher Full Text | Free Full Text | F1000 Recommendation

87. F Xu X, Tao Y, Gao X, et al:: A CRISPR-based approach for targeted DNA demethylation. Cell Discov. 2016; 2: 16009.

PubMed Abstract | Publisher Full Text | Free Full Text | F1000 Recommendation

88. F Morita S, Noguchi $\mathrm{H}$, Horii $\mathrm{T}$, et al.: Targeted DNA demethylation in vivo using dCas9-peptide repeat and scFv-TET1 catalytic domain fusions. Nat Biotechnol. 2016; 34(10): 1060-5.

PubMed Abstract | Publisher Full Text | F1000 Recommendation

89. F Choudhury SR, Cui Y, Lubecka K, et al.: CRISPR-dCas9 mediated TET1 targeting for selective DNA demethylation at BRCA1 promoter. Oncotarget. 2016; 7(29): 46545-56.

PubMed Abstract | Publisher Full Text | Free Full Text | F1000 Recommendation

90. F McDonald JI, Celik H, Rois LE, et al.: Reprogrammable CRISPR/Cas9-based system for inducing site-specific DNA methylation. Biol Open. 2016; 5(6): 866-74. PubMed Abstract | Publisher Full Text | Free Full Text | F1000 Recommendation

91. F Vojta A, Dobrinić P, Tadić V, et al.: Repurposing the CRISPR-Cas9 system for targeted DNA methylation. Nucleic Acids Res. 2016; 44(12): 5615-28. PubMed Abstract | Publisher Full Text | Free Full Text | F1000 Recommendation

92. F Amabile A, Migliara A, Capasso $\mathrm{P}$, et al:: Inheritable Silencing of Endogenous Genes by Hit-and-Run Targeted Epigenetic Editing. Cell. 2016; 167(1): 219-232.e14.

PubMed Abstract | Publisher Full Text | Free Full Text | F1000 Recommendation

93. Nihongaki $Y$, Yamamoto S, Kawano F, et al: CRISPR-Cas9-based photoactivatable transcription system. Chem Biol. 2015; 22(2): 169-74. PubMed Abstract | Publisher Full Text

94. F Polstein LR, Gersbach CA: A light-inducible CRISPR-Cas9 system for control of endogenous gene activation. Nat Chem Biol. 2015; 11(3): 198-200. PubMed Abstract | Publisher Full Text | Free Full Text | F1000 Recommendation

95. Zetsche B, Volz SE, Zhang F: A split-Cas9 architecture for inducible genome editing and transcription modulation. Nat Biotechnol. 2015; 33(2): 139-42. PubMed Abstract | Publisher Full Text | Free Full Text

96. F Oakes BL, Nadler DC, Flamholz A, et al:: Profiling of engineering hotspots identifies an allosteric CRISPR-Cas9 switch. Nat Biotechnol. 2016; 34(6): 646-51. PubMed Abstract | Publisher Full Text | Free Full Text | F1000 Recommendation

97. F Esvelt KM, Mali P, Braff JL, et al:: Orthogonal Cas9 proteins for RNA-guided gene regulation and editing. Nat Methods. 2013; 10(11): 1116-21. PubMed Abstract | Publisher Full Text | Free Full Text | F1000 Recommendation

98. Fonfara I, Le Rhun A, Chylinski K, et al:: Phylogeny of Cas9 determines functional exchangeability of dual-RNA and Cas9 among orthologous type II CRISPR-Cas systems. Nucleic Acids Res. 2014; 42(4): 2577-90. PubMed Abstract | Publisher Full Text | Free Full Text

99. Briner AE, Donohoue PD, Gomaa AA, et al:: Guide RNA functional modules direct Cas9 activity and orthogonality. Mol Cell. 2014; 56(2): 333-9. PubMed Abstract | Publisher Full Text

100. Gao $\mathrm{Y}$, Xiong $\mathrm{X}$, Wong $\mathrm{S}$, et al:: Complex transcriptional modulation with orthogonal and inducible dCas9 regulators. Nat Methods. 2016; 13(12): 1043-9. PubMed Abstract | Publisher Full Text | Free Full Text

101. F Bao Z, Jain S, Jaroenpuntaruk V, et al:: Orthogonal Genetic Regulation in Human Cells Using Chemically Induced CRISPR/Cas9 Activators. ACS Synth Biol. 2017; 6(4): 686-693.

PubMed Abstract | Publisher Full Text | F1000 Recommendation

102. F Shechner DM, Hacisuleyman E, Younger ST, et al:: Multiplexable, locusspecific targeting of long RNAs with CRISPR-Display. Nat Methods. 2015; 12(7): 664-70.

PubMed Abstract | Publisher Full Text | Free Full Text | F1000 Recommendation

103. F Maji B, Moore CL, Zetsche B, et al:: Multidimensional chemical control of CRISPR-Cas9. Nat Chem Biol. 2017; 13(1): 9-11.

PubMed Abstract | Publisher Full Text | F1000 Recommendation

104. $\mathrm{F}$ Liu $\mathrm{Y}$, Zhan $\mathrm{Y}, \mathrm{Chen} \mathrm{Z}$, et al.: Directing cellular information flow via CRISPR signal conductors. Nat Methods. 2016; 13(11): 938-44. PubMed Abstract | Publisher Full Text | F1000 Recommendation

105. Kiani S, Beal J, Ebrahimkhani MR, et al.: CRISPR transcriptional repression devices and layered circuits in mammalian cells. Nat Methods. 2014; 11(7): 723-6.

PubMed Abstract | Publisher Full Text | Free Full Text

106. Wright AV, Sternberg SH, Taylor DW, et al.: Rational design of a split-Cas 9 enzyme complex. Proc Natl Acad Sci U S A. 2015; 112(10): 2984-9. PubMed Abstract | Publisher Full Text | Free Full Text

107. Truong DJ, Kühner K, Kühn R, et al.: Development of an intein-mediated splitCas9 system for gene therapy. Nucleic Acids Res. 2015; 43(13): 6450-8. PubMed Abstract | Publisher Full Text | Free Full Text

108. Nishimasu H, Cong L, Yan WX, et al.: Crystal Structure of Staphylococcus aureus Cas9. Cell. 2015; 162(5): 1113-26. PubMed Abstract | Publisher Full Text | Free Full Text

109. Ramakrishna S, Kwaku Dad AB, Beloor J, et al:: Gene disruption by cellpenetrating peptide-mediated delivery of Cas9 protein and guide RNA. Genome Res. 2014; 24(6): 1020-7.

PubMed Abstract | Publisher Full Text | Free Full Text

110. F Zuris JA, Thompson DB, Shu Y, et al:: Cationic lipid-mediated delivery of proteins enables efficient protein-based genome editing in vitro and in vivo. Nat Biotechnol. 2015; 33(1): 73-80. PubMed Abstract | Publisher Full Text | Free Full Text | F1000 Recommendation

111. Kim S, Kim D, Cho SW, et al:: Highly efficient RNA-guided genome editing in human cells via delivery of purified Cas 9 ribonucleoproteins. Genome Res. 2014; 24(6): 1012-9. PubMed Abstract | Publisher Full Text | Free Full Text

112. Nihongaki Y, Kawano F, Nakajima T, et al:: Photoactivatable CRISPR-Cas9 for optogenetic genome editing. Nat Biotechnol. 2015; 33(7): 755-60. PubMed Abstract | Publisher Full Text

113. Dow LE, Fisher J, O'Rourke KP, et al:: Inducible in vivo genome editing with CRISPR-Cas9. Nat Biotechnol. 2015; 33(4): 390-4. PubMed Abstract | Publisher Full Text | Free Full Text

114. F González F, Zhu Z, Shi ZD, et al:: An iCRISPR platform for rapid, multiplexable, and inducible genome editing in human pluripotent stem cells. Cell Stem Cell. 2014; 15(2): 215-26. PubMed Abstract | Publisher Full Text | Free Full Text | F1000 Recommendation

115. Hemphill J, Borchardt EK, Brown K, et al.: Optical Control of CRISPR/Cas9 Gene Editing. J Am Chem Soc. 2015; 137(17): 5642-5. PubMed Abstract | Publisher Full Text | Free Full Text

116. Jain PK, Ramanan V, Schepers AG, et al.: Development of Light-Activated CRISPR Using Guide RNAs with Photocleavable Protectors. Angew Chem Int Ed Engl. 2016; 55(40): 12440-4. PubMed Abstract | Publisher Full Text 
117. Aubrey BJ, Kelly GL, Kueh AJ, et al:: An inducible lentiviral guide RNA platform enables the identification of tumor-essential genes and tumor-promoting mutations in vivo. Cell Rep. 2015; 10(8): 1422-32. PubMed Abstract | Publisher Full Text

118. Davis KM, Pattanayak V, Thompson DB, et al.: Small molecule-triggered Cas9 protein with improved genome-editing specificity. Nat Chem Biol. 2015; 11(5): 316-8. PubMed Abstract | Publisher Full Text | Free Full Text

119. F Wang T, Wei JJ, Sabatini DM, et al:: Genetic screens in human cells using the CRISPR-Cas9 system. Science. 2014; 343(6166): 80-4. PubMed Abstract | Publisher Full Text | Free Full Text | F1000 Recommendation

120. Carthew RW, Sontheimer EJ: Origins and Mechanisms of miRNAs and siRNAs. Cell. 2009; 136(4): 642-55 PubMed Abstract | Publisher Full Text | Free Full Text

121. Mello CC, Conte D Jr: Revealing the world of RNA interference. Nature. 2004 431(7006): 338-42. PubMed Abstract | Publisher Full Text

122. Hutvagner G, Simard MJ: Argonaute proteins: key players in RNA silencing. Nat Rev Mol Cell Biol. 2008; 9(1): 22-32. PubMed Abstract | Publisher Full Text

123. Ha M, Kim VN: Regulation of microRNA biogenesis. Nat Rev Mol Cell Biol. 2014 15(8): 509-24. PubMed Abstract | Publisher Full Text

124. Prelich G: Gene overexpression: uses, mechanisms, and interpretation. Genetics. 2012; 190(3): 841-54. PubMed Abstract | Publisher Full Text | Free Full Text

125. F Porteus $\mathrm{MH}$, Baltimore $\mathrm{D}$ : Chimeric nucleases stimulate gene targeting in human cells. Science. 2003; 300(5620): 763 PubMed Abstract | Publisher Full Text | F1000 Recommendation

126. Miller JC, Holmes MC, Wang J, et al:: An improved zinc-finger nuclease architecture for highly specific genome editing. Nat Biotechnol. 2007; 25(7): 778-85. PubMed Abstract | Publisher Full Text

127. F Sander JD, Dahlborg EJ, Goodwin MJ, et al:: Selection-free zinc-fingernuclease engineering by context-dependent assembly (CoDA). Nat Methods. 2011; 8(1): 67-9.

PubMed Abstract | Publisher Full Text | Free Full Text | F1000 Recommendation

128. F Wood AJ, Lo TW, Zeitler B, et al:: Targeted genome editing across species using ZFNs and TALENs. Science. 2011; 333(6040): 307. PubMed Abstract | Publisher Full Text | Free Full Text | F1000 Recommendation

129. Christian M, Cermak T, Doyle EL, et al:: Targeting DNA double-strand breaks with TAL effector nucleases. Genetics. 2010; 186(2): 757-61. PubMed Abstract | Publisher Full Text | Free Full Text

130. F Zhang F, Cong L, Lodato $S$, et al:: Efficient construction of sequencespecific TAL effectors for modulating mammalian transcription. Nat Biotechnol.
2011; 29(2): 149-53

PubMed Abstract | Publisher Full Text | Free Full Text | F1000 Recommendation

131. F Hockemeyer D, Wang H, Kiani S, et al.: Genetic engineering of human pluripotent cells using TALE nucleases. Nat Biotechnol. 2011; 29(8): 731-4. PubMed Abstract | Publisher Full Text | Free Full Text | F1000 Recommendation

132. F Reyon D, Tsai SQ, Khayter C, et al:: FLASH assembly of TALENs for highthroughput genome editing. Nat Biotechnol. 2012; 30(5): 460-5. PubMed Abstract | Publisher Full Text | Free Full Text | F1000 Recommendation

133. F Boch J, Scholze H, Schornack S, et al:: Breaking the code of DNA binding specificity of TAL-type III effectors. Science. 2009; 326(5959): 1509-12. PubMed Abstract | Publisher Full Text | F1000 Recommendation

134. F Moscou MJ, Bogdanove AJ: A simple cipher governs DNA recognition by TAL effectors. Science. 2009; 326(5959): 1501.

PubMed Abstract | Publisher Full Text | F1000 Recommendation

135. Sanjana NE, Cong L, Zhou Y, et al:: A transcription activator-like effector toolbox for genome engineering. Nat Protoc. 2012; 7(1): 171-92. PubMed Abstract | Publisher Full Text | Free Full Text

136. Zhao $Y$, Dai $Z$, Liang $Y$, et al:: Sequence-specific inhibition of microRNA via CRISPR/CRISPRi system. Sci Rep. 2014; 4: 3943. PubMed Abstract | Publisher Full Text | Free Full Text

137. Choo Y, Isalan M: Advances in zinc finger engineering. Curr Opin Struct Biol. 2000; 10(4): 411-6. PubMed Abstract | Publisher Full Text

138. Sera $\mathrm{T}$ : Zinc-finger-based artificial transcription factors and their applications. Adv Drug Deliv Rev. 2009; 61(7-8): 513-26. PubMed Abstract | Publisher Full Text

139. Cong L, Zhou R, Kuo YC, et al:: Comprehensive interrogation of natural TALE DNA-binding modules and transcriptional repressor domains. Nat Commun. 2012; 3: 968. PubMed Abstract | Publisher Full Text | Free Full Text

140. Garg A, Lohmueller JJ, Silver PA, et al.: Engineering synthetic TAL effectors with orthogonal target sites. Nucleic Acids Res. 2012; 40(15): 7584-95. PubMed Abstract | Publisher Full Text | Free Full Text

141. Mahfouz MM, Li L, Piatek M, et al:: Targeted transcriptional repression using a chimeric TALE-SRDX repressor protein. Plant Mol Biol. 2012; 78(3): 311-21. PubMed Abstract | Publisher Full Text | Free Full Text

142. Maeder ML, Linder SJ, Reyon D, et al.: Robust, synergistic regulation of human gene expression using TALE activators. Nat Methods. 2013; 10(3): 243-5. PubMed Abstract | Publisher Full Text | Free Full Text

143. Polstein LR, Perez-Pinera P, Kocak DD, et al.: Genome-wide specificity of DNA binding, gene regulation, and chromatin remodeling by TALE- and CRISPR/ Cas9-based transcriptional activators. Genome Res. 2015; 25(8): 1158-69. PubMled Abstract | Publisher Full Text | Free Full Text 


\section{Open Peer Review}

\section{Current Peer Review Status:}

\section{Editorial Note on the Review Process}

Faculty Reviews are review articles written by the prestigious Members of Faculty Opinions. The articles are commissioned and peer reviewed before publication to ensure that the final, published version is comprehensive and accessible. The reviewers who approved the final version are listed with their names and affiliations.

\section{The reviewers who approved this article are:}

\section{Version 1}

\section{Rodolphe Barrangou}

Department of Food, Bioprocessing, and Nutrition Sciences, North Carolina State University, Raleigh, NC, USA

Competing Interests: No competing interests were disclosed.

2. Charles Gersbach

Department of Biomedical Engineering, Center for Genomic \& Computational Biology, Duke University, Durham, NC, USA

Competing Interests: No competing interests were disclosed.

\section{Luciano Marraffini}

Laboratory of Bacteriology, Rockefeller University, New York, NY, 10065, USA

Competing Interests: No competing interests were disclosed.

The benefits of publishing with F1000Research:

- Your article is published within days, with no editorial bias

- You can publish traditional articles, null/negative results, case reports, data notes and more

- The peer review process is transparent and collaborative

- Your article is indexed in PubMed after passing peer review

- Dedicated customer support at every stage

For pre-submission enquiries, contact research@f1000.com 